\title{
Fatty acid and triacylglycerol composition of the subcutaneous fat from iberian pigs fattened on the traditional feed: "Montanera". effect of anatomical location and length of feeding
}

\author{
By Mónica Narváez-Rivas, ${ }^{1}$ Manuel León-Camacho ${ }^{1 *}$ and Isabel M. Vicario ${ }^{2}$ \\ ${ }^{1}$ Food Characterization and Quality Department, Instituto de la Grasa (C.S.I.C.). \\ Av. Padre García Tejero, 4. 41012 Seville, Spain. \\ ${ }^{2}$ Department of Food Science and Nutrition. Faculty of Pharmacy. \\ University of Seville. Spain. \\ ( ${ }^{*}$ Corresponding author: mleon@ @ica.es)
}

\section{RESUMEN}

\begin{abstract}
Composición de los ácidos grasos y triglicéridos de la grasa subcutánea de cerdos ibéricos alimentados por el sistema tradicional de Montanera. Efecto de la localización anatómica y el tiempo de cebado.
\end{abstract}

Se ha determinado la composición de ácidos grasos y de triglicéridos en 200 muestras de grasa subcutánea procedentes de dos localizaciones anatómicas (rabadilla y tejido adiposo que recubre el músculo Biceps femoris) de cerdos ibéricos puros alimentados en "Montanera". Se encontraron diferencias significativas para la mayoría de ácidos grasos y para algunos triglicéridos PPS, PLPo + MLO, PLO, PLL + PoLO, SOS, SOL, OLL) entre las dos localizaciones anatómicas, siendo la rabadilla la menos saturada. El nivel de actividad de la enzima involucrada en la lipogénesis defirió significativamente $(p<0.0001)$ entre ambos tejidos. También se investigó el efecto de la campaña en la composición de ácidos grasos y triglicéridos. Se encontró un aumento en la relación oleico/esteárico en campañas con bajos recursos. Esto indica un incremento en la actividad de la Stearyl-CoA desaturasa. Además, las diferencias encontradas entre ambas grasas subcutáneas durante el periodo de engorde, indica que la insaturación de la grasa subcutánea que recubre un músculo con alto metabolismo oxidativo, como el B. femoris, aumenta más rápidamente que la de la grasa subcutánea que recubre un músculo con bajo metabolismo oxidativo, como el Longissimus dorsi.

PALABRAS CLAVE: Ácidos grasos - Cerdo ibérico Grasa subcutánea - Localización anatómica - Triglicéridos.

\section{SUMMARY}

Fatty acid and triacylglycerol composition of the subcutaneous fat from lberian pigs fattened on the traditional feed: "Montanera". Effect of anatomical location and length of feeding.

Fatty acid and triacylglycerol compositions of 200 samples of subcutaneous fat from two different anatomical locations (rump and adipose tissue covering the Biceps femoris muscle) of Iberian purebred pigs reared on "Montanera" were determined. Significant differences were found for the majority fatty acids and for some triacylglycerol species (PPS, PLPo + MLO, PLO, PLL + PoLO, SOS, SOL, OLL) among the two anatomical locations, being the rump location less saturated. The activity level of the key enzyme involved in lipogenesis differed $(p<0.0001)$ significantly between both tissues. The effect of campaign on the fatty acid and triacylglycerol composition was also explored. An increase on the ratio oleic/stearic has been found in campaigns with low resources. This indicates an increase on the activity of Stearoyl-CoA desaturase. Besides, the differences found between both subcutaneous fats during the fattening period indicates that the unsaturation of the subcutaneous fat covering a muscle with high oxidative metabolism, as Biceps femoris, increases faster than that of the subcutaneous fat covering a muscle with low oxidative metabolism, as Longissimus dorsi.

KEY-WORDS: Anatomical location - Fatty acids Iberian pig - Subcutaneous fat - Triacylglicerols.

\section{INTRODUCTION}

Dietary lipids are the main factor that determines the fatty acid and triacylglycerols profile of body fat in non-ruminant animals (Viera-Alcaide et al., 2007). In the Iberian pig industry, the finishing diet of the animals previous to slaughter is considered one of the main factors affecting the quality of the corresponding dry-cured products (López Bote, 1998). The highest quality products are those derived from animals grown extensively in the traditional feeding system, usually called "Montanera" (M), in which animals are reared outdoor and grazed on acorns (Quercus spp) and pasture. For less quality products, "Cebo" (C) and "Recebo" (R) the feeding system also includes formulated feeds. It's established by law a minimum of two months eating acorn and pasture to gain at least $46 \mathrm{Kg}$, during the fattening period of Montanera pigs (B.O.E., 2007). The contents of four fatty acids (palmitic, stearic, oleic and linoleic) in a sample of subcutaneous adipose tissue from the animals' rump are often used by industry to classify commercially the pig carcasses in the three categories cited before: "Montanera", "Recebo" and "Cebo". These values are established each year by industry and producers, but are not as reliable as they should be since many animals are misclassified.

The anatomical locations of the fat deposited in pig carcass are four: visceral, subcutaneous, intermuscular or intramuscular. The effect of the 
feeding system on the subcutaneous and intramuscular lipids in fresh and cured hams of Iberian pigs has been extensively studied in several papers (Tejeda et al., 2002; Cava et al., 1997; García et al., 1996; García-Rey et al., 2005; Viera Alcaide et al., 2008). Several authors (Monziols et al., 2007) have reported variation in fatty acid composition of different anatomical locations (Sharma et al., 1987; Franco et al., 2006; Monziols et al., 2007). However, few have studied the influence of the feeding length in montanera on the triacylglycerol composition and fatty acid profile (Díaz et al., 1996; Viera-Alcaide et al., 2008).

The aims of this work have been: (1) to study and compare the triacylglycerol and fatty acid composition of two anatomical locations: the subcutaneous fat from rump $(R)$ and the adipose tissue covering the $B$. femoris muscle $(H)$ in animals fed in Montanera during different periods of time. (2) To explore how the length of montanera influences the fatty acid and tryacilglicerol composition of the subcutaneous fat in this two anatomical locations.

\section{MATERIAL AND METHODS}

\subsection{Animals and diets}

200 castrated male pure Iberian pigs, produced under the guidelines of the Designation of Origin "Jamón de Huelva", were used, which were selected according the traditional diet with acorns and pasture ("bellota") and two fattening periods: short "Montanera" (M1 < 90 days) and long "Montanera" (M2 between 91 and 120 days), from three consecutive campaigns: 104 animals corresponding to campaign 2002-2003 (M1 = 15; $\mathrm{M} 2=89), 68$ animals corresponding to campaign 2003-2004 ( $M 1=30 ; M 2=38)$ and 28 animals corresponding to campaign 2004-2005 (M1 = 1; $\mathrm{M} 2=27)$.

\subsection{Sampling}

Of each animal slaughtered two samples of adipose tissue were taken. One, a sample consisting of a chunk between $3 \times 3$ and $5 \times 5 \mathrm{~cm}$ approximately, of at least $6 \mathrm{~mm}$ of thickness by cutting the rump $(R)$, at approximately $10 \mathrm{~cm}$ of the tail following the line of the back and containing skin, adipose tissue and some loin, according to the official method (B.O.E., 2004). In the laboratory the skin and the loin were removed. All the chunks corresponding to each animal sacrifice were punctured and homogenized before extraction.

Of each animal, another sample was taken from the subcutaneous adipose tissue covering the $B$. femoris muscle of both hams $(\mathrm{H})$. Both portions were mixed.

All samples were then obtained by melting the fat in an oven microwave (De Pedro et al., 1997), where it remained during 3 minutes at $360 \mathrm{~W}$ of power. The samples of fat were then filtered and prepared for the analysis.

\subsection{Fatty acids and triacylglycerols analysis}

Fatty acid methyl esters (FAME) were analyzed by GC. FAME were extracted with $\mathrm{n}$ hexane after cold methylation with $2 \mathrm{~N} \mathrm{KOH}$ in methanol, following the official method (B.O.E., 2004). GC was performed with a Varian 3900 apparatus (Varian Co, Palo Alto, CA, USA) using a fused silica capillary HP 88 column $(100 \mathrm{~m} \times 0.25 \mathrm{~mm}, 0.25 \mu \mathrm{m}$ film thickness). The oven temperature was kept at $175^{\circ} \mathrm{C}$ for $13 \mathrm{~min}$. and was then raised to $205^{\circ} \mathrm{C}$ at a rate of $3.0^{\circ} \mathrm{C} / \mathrm{min}$ and held isothermally for 5.0 min. The injector temperature was kept at $240{ }^{\circ} \mathrm{C}$, while the detector temperature was $250^{\circ} \mathrm{C}$. Hydrogen (131 kPa inlet pressure) was used as carrier gas, while the make-up gas was nitrogen.

Triacylglycerols were analyzed by GC (VieraAlcaide et al., 2007) in a Varian 3800 (Varian Co, Palo Alto, CA, USA) using a fused silica capillary DB-17HT column $(30 \mathrm{~m} \times 0.32 \mathrm{~mm}$ I.D., $0.15 \mu \mathrm{m}$ film thickness). The oven temperature was kept at $330{ }^{\circ} \mathrm{C}$, and was then raised to $360{ }^{\circ} \mathrm{C}$ at a rate of $2.0^{\circ} \mathrm{C} / \mathrm{min}$ and held isothermally for $10 \mathrm{~min}$. The injector temperature was kept at $360{ }^{\circ} \mathrm{C}$, while the detector temperature was $370{ }^{\circ} \mathrm{C}$. Hydrogen (5.3 $\mathrm{mL} / \mathrm{min}$ column constant flow) was used as carrier gas, while the make-up gas was nitrogen.

\subsection{Statistical analysis}

Data were collected during three consecutives seasons. Quantification of the chemical compounds was carried out with Varian Chromatography Workstation software, version 6.41. The data were analysed using Statistica v 8.0 software (Statsoft Inc., 2008). In other to explore if there were significant differences between anatomical location, campaigns and "Montanera" feeding length, main effects analysis of variance (ANOVA) was performed according to the general lineal model procedure.

\section{RESULTS AND DISCUSSION}

\subsection{Anatomical location}

Table 1 shows the average percentage of total triacylglycerols and fatty acids in the subcutaneous fat of Iberian pigs, according to the anatomical locations. The statistical analysis of the results showed that the $\mathrm{R}$ and $\mathrm{H}$ composition were significantly different in relation to the fatty acid profile. The largest differences $(p<0.0001)$ between anatomical locations were observed for the saturated fatty acids palmitic and stearic and for the unsaturated linoleic acid, which is an essential fatty acid for pigs and so, coming exclusively from feed. The $R$ was significantly $(p<0.0001)$ less 
Table 1

Fatty acid and triacylglycerol profiles of Iberian pig subcutaneous fat from different anatomical locations *

\begin{tabular}{|c|c|c|c|c|}
\hline & \multicolumn{2}{|c|}{$\begin{array}{c}R \\
(n=200)\end{array}$} & \multicolumn{2}{|c|}{$\begin{array}{c}H \\
(n=200)\end{array}$} \\
\hline & Means & S.D. & Means & S.D. \\
\hline C14:0 & 1.18 & 0.13 & 1.19 & 0.12 \\
\hline $\mathrm{C} 16: 0^{\mathrm{d}}$ & 20.03 & 0.94 & 20.55 & 1.12 \\
\hline C16:1 & 2.04 & 0.31 & 2.01 & 0.33 \\
\hline $\mathrm{C} 17: 0^{\mathrm{C}}$ & 0.30 & 0.05 & 0.28 & 0.05 \\
\hline $\mathrm{C} 17: 1^{\mathrm{b}}$ & 0.28 & 0.06 & 0.26 & 0.06 \\
\hline C18:0 $0^{d}$ & 9.46 & 1.07 & 9.95 & 1.17 \\
\hline C18:1 $1^{b}$ & 55.75 & 1.45 & 55.27 & 1.65 \\
\hline C18:2 & 8.51 & 0.68 & 8.19 & 0.72 \\
\hline C18:3 & 0.58 & 0.16 & 0.55 & 0.14 \\
\hline C20:0 & 0.19 & 0.03 & 0.19 & 0.03 \\
\hline $\mathrm{C} 20: 1^{\mathrm{d}}$ & 1.66 & 0.23 & 1.54 & 0.22 \\
\hline$S F A^{d}$ & 31.18 & 1.72 & 32.17 & 2.04 \\
\hline MUFA $^{b}$ & 59.73 & 1.48 & 58.81 & 4.24 \\
\hline PUFA $^{d}$ & 9.09 & 0.78 & 8.74 & 0.81 \\
\hline PPP & 0.19 & 0.08 & 0.19 & 0.09 \\
\hline MOP & 0.73 & 0.18 & 0.72 & 0.20 \\
\hline$P S^{a}$ & 0.62 & 0.21 & 0.67 & 0.23 \\
\hline POP & 4.98 & 0.82 & 5.07 & 0.93 \\
\hline POPO + PLP & 4.22 & 1.03 & 4.09 & 1.08 \\
\hline$P L P O+M^{\prime}{ }^{d}$ & 0.78 & 0.13 & 0.72 & 0.12 \\
\hline$P_{S S}^{a}$ & 0.88 & 0.26 & 0.94 & 0.32 \\
\hline $\mathrm{PSO}^{d}$ & 13.19 & 1.90 & 14.12 & 2.03 \\
\hline POO & 32.34 & 2.14 & 32.31 & 2.09 \\
\hline $\mathrm{PLO}^{\mathrm{d}}$ & 10.29 & 0.92 & 9.90 & 0.90 \\
\hline PLL + PoLO ${ }^{d}$ & 1.38 & 0.20 & 1.26 & 0.19 \\
\hline $\operatorname{SOS}^{c}$ & 1.27 & 0.22 & 1.38 & 0.41 \\
\hline SOO & 6.87 & 0.65 & 6.95 & 0.74 \\
\hline 000 & 11.41 & 1.39 & 11.23 & 1.56 \\
\hline $\mathrm{SOL}^{d}$ & 3.83 & 0.39 & 3.64 & 0.33 \\
\hline OOL & 5.91 & 0.88 & 5.76 & 0.96 \\
\hline $\mathrm{OLL}^{\mathrm{a}}$ & 1.10 & 0.27 & 1.04 & 0.28 \\
\hline DBN 0 & 1.70 & 0.52 & 1.81 & 0.59 \\
\hline $\mathrm{DBN} 1^{\mathrm{c}}$ & 20.17 & 2.83 & 21.30 & 3.05 \\
\hline DBM 2 & 43.43 & 1.38 & 43.34 & 1.32 \\
\hline $\mathrm{DBN} 3^{\mathrm{d}}$ & 26.31 & 1.82 & 25.48 & 2.07 \\
\hline DBN $4^{b}$ & 7.30 & 0.92 & 7.02 & 1.04 \\
\hline $\mathrm{R} 1^{\mathrm{b}}$ & 0.10 & 0.01 & 0.10 & 0.02 \\
\hline$R 2^{d}$ & 5.98 & 0.78 & 5.64 & 0.76 \\
\hline
\end{tabular}

* Data are mean values. Abbreviations: S.D., standard deviation; $\mathrm{R}$, rump; $\mathrm{H}$, adipose tissue covering the Biceps femoris muscle. Different letters indicate significant differences between rump and ham data: $a$ for $p<0.05$, b for $p<0.01, c$ for $p<0.001$ and $d$ for $p<0.0001$.

saturated than the $\mathrm{H}$ sample (31. $18 \%$ vs $32.17 \%$ ) and with a significant $(P<0.0001)$ higher content of polyunsaturated fatty acids (PUFA) $(9.09 \%$ vs $8.74 \%$ ). Previous studies have shown differences in the fatty acid composition of the inner and the outer layers of subcutaneous fat from different anatomical locations in pigs (Bee et al., 2008; Monziols et al, 2007). It has been reported that the outer layer is more unsaturated than the inner layer. The differences found between the $\mathrm{R}$ and the $\mathrm{H}$ in this study resembles those reported by different authors between the outer and the inner layers of adipose tissues, respectively (Bee et al., 2002; Monziols et al., 2007; Daza et al., 2007). The preferential deposition of PUFA (mainly linolenic acid) in the outer layer of the pig adipose tissues is not still fully understood. It has been postulated that it may be related to the lower lipid metabolism in the outer layer (Monziols et al., 2007). On the contrary, the larger novo lypogenesis activity in the inner layer may dilute the dietary PUFA (mainly linolenic acid) with endogenous fatty acids (Bee et al., 2002).

There is also a significant difference $(p<0.001)$ in the monounsaturated fatty acids (MUFA) content between the $\mathrm{H}$ and $\mathrm{R}$. The proportion of oleic acid, the main MUFA in pig adipose tissue is determined by the dietary supply as well as by endogenous synthesis by a $\Delta^{9-}$ desaturase. The traditional feed of montanera pigs is based on acorn and pasture which provides a high dietary intake of oleic acid, coming mainly from the acorns, which contain $60 \%$ of this fatty acid (LeónCamacho et al., 2004). Stearoyl-CoA desaturase (SCD) is a lipogenic enzyme that catalyzes the synthesis of monounsaturated fatty acids, (Kouba and Mourot, 1998). Although, we did not measured the activity of the SCD enzyme in this study, the desaturation index $\left(R_{1}=\right.$ Palmitoleic/palmitic; and $R_{2}$ $=$ oleic/stearic) have been reported to relate well with the activity of this enzyme (Klingenberg et al., 1995; Kouba et al., 1997). The activity level of the key enzyme involved in lipogenesis differed significantly between both tissues, $p<0.01$ for $R_{1}$ and $p<0.0001$ for $R_{2}$ (Table 1). The conversion of palmitic and stearic acids into their unsaturated homologs was significantly lower $(p<0.0001)$ in the $H$ than in the $R$. Previous studies by Buller and Enser (1986) suggested that SCD is tissue specific, and the differences could be related to the lower content of linoleic acid in the $\mathrm{H}$ than in the $\mathrm{R}$. This is in accordance with data reported for the outer and inner layers of subcutaneous backfat of Iberian pigs fed under free range conditions (Daza et al., 2007).

Despite these differences, the lipid profile of the subcutaneous fat from $\mathrm{R}$ and $\mathrm{H}$ showed a very similar profile, with four fatty acids that accounted for more than $90 \%$ of total fatty acids: oleic acid, palmitic acid, stearic acid, and linoleic acid. These results are in agreement with the fatty acid profile of Iberian pig previously published by other authors (Narváez-Rivas et al., 2008).

The triacylglycerol composition also showed differences between the two anatomical locations. Grouping the triacylglycerols according to the number of double bonds (DBN), there were significant differences $(p<0.0001)$ for DBN 3, DBN $1(p<0.001)$ and DBN $4(p<0.01)$. The most unsaturated triacylglycerols (DBN 3 and DBN 4) showed significant higher values for the $R$ than for the $\mathrm{H}$. In accordance with the results previously described for fatty acids, those triacylglycerols containing the saturated fatty acid palmitic and stearic (PSS and PPS) were more abundant ( $p<$ 0.05 ) in the $\mathrm{H}$ than in the $\mathrm{R}$. On the contrary those containing linoleic acid (PLO; PLL + PoLO; SOL; OLL) were significantly increased in the R. Other triacylglycerols containing oleic acid (PSO and SOS) showed higher values in the $\mathrm{H}$ than in the $\mathrm{R}$. 
In agreement with previous studies (Monziols et al., 2007; Franco et al., 2006) the saturation degree of the fat deposits in pigs showed an increasing gradient from inwards outside.

Despite these differences, the triacylglycerol composition of the two anatomical locations of the subcutaneous fat showed a very similar profile, with six triacylglycerol species accounting for more than $75 \%$ of total triacylglycerols: POO, PSO, POL, OOO, SOO, and OOL (Viera-Alcaide et al., 2008).

\subsection{Campaign}

Among the factors that modify the fat profile of the pig' tissues are the amount of carbohydrates and the fat profile of the diet, and the duration of the fattening period (Cava López and Andrés Nieto, 2001). During the "Montanera" fattening period, the pigs are fed exclusively on fallen acorns and pasture. Recent studies suggest (Rodríguez-Estévez et al., 2008) a daily dry matter intake of $3.1-3.6 \mathrm{~kg}$ of acorn kernel and $0.38-0.49 \pm 0.04 \mathrm{~kg}$ of grass. Although we have no data on the diet composition of the three campaigns included in the study, we can suppose that they were quite different in the feed availability, since they were significantly different in terms of rains (Figure 1) and temperatures which are factors related with pasture and acorn production. It has been reported that acorn (Quercus ilex) production is positively correlated with minimum temperatures, relative humidity and rains in January; rains in March, relative humidity in April and mean temperature in June and September rains (Rodríguez-Estévez et al., 2007; García-Mozo et al., 2007). According to this we have considered the three campaigns as a high resource campaign (HRC) corresponding to 2003, medium resource campaigns (MRC) corresponding to 2004 and low resource campaigns (LRC) corresponding to 2005. The animals included in this study were fattened in "Montanera" for different periods and so we can suppose significant differences in the feed resources availability in each campaign. The animals reached the adequate weight at slaughter. Bee et al. (2002) reported no differences in body weight at slaughter between animals fed Low vs High energy diets, although growth performance and carcass measurement were affected $(p<0.01)$ by the energy concentration. They also reported that food restriction could alter the relationship between intake of fatty acids and both the absolute and relative content of individual fatty acids in adipose tissues. In accordance to this, we found significant differences for individual fatty acids in the three campaigns for both tissues. Tables 2 and 3 show the fat profile of the two anatomical locations ( $R$ and $\mathrm{H}$ ) grouped by campaigns. It can be observed that a restriction of feed resources (LRC) increased the level of linoleic acid in both anatomical locations $(7.17 \%$ for $\mathrm{R}$ and $6.11 \%$ for $\mathrm{H})$ when compared to the high resource campaign (HRC). The inverse trend was observed for stearic acid. In the campaign with restriction of feed

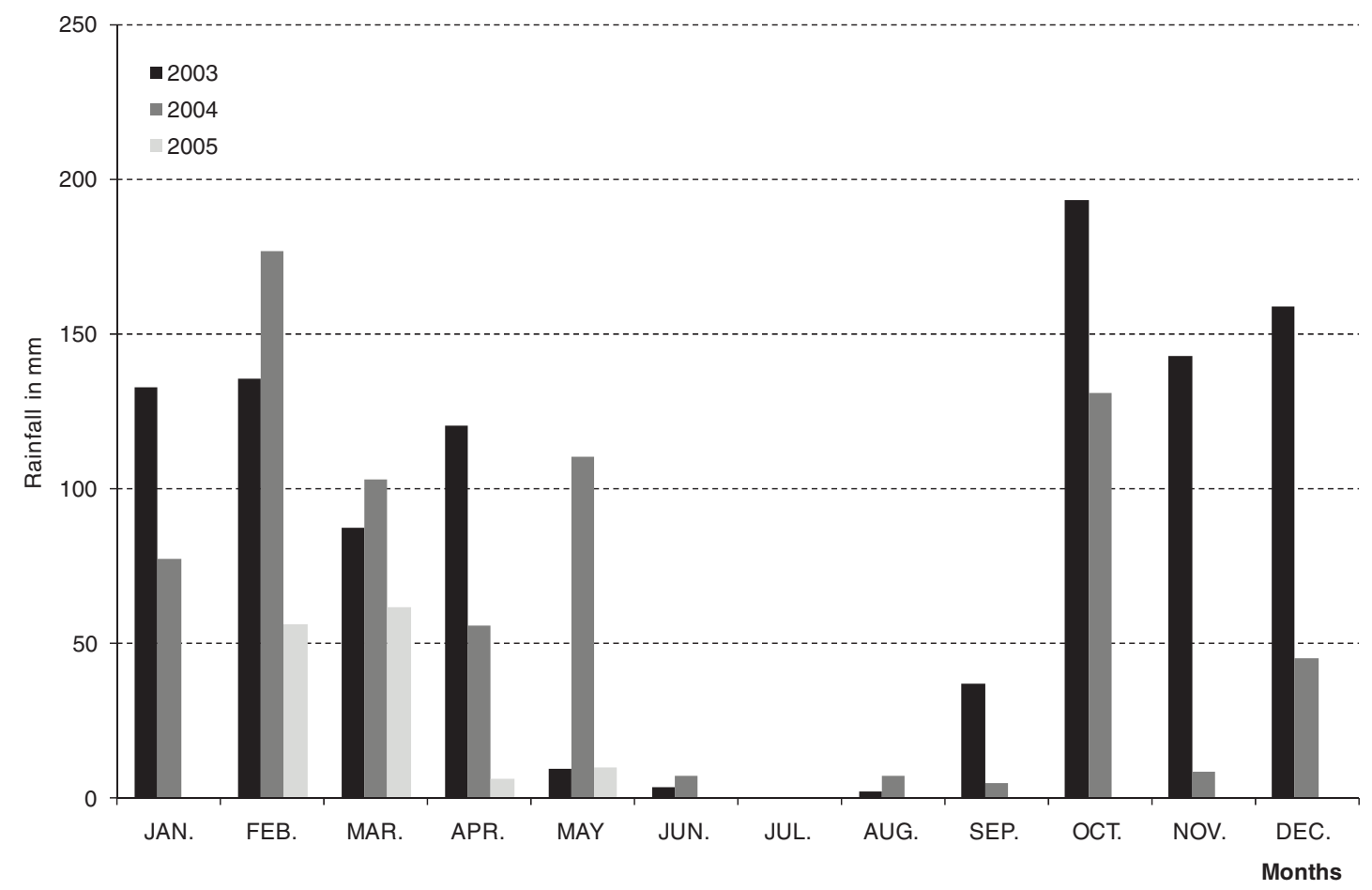

Figure 1.

Means value of rainfall from different regions (Alajar, Aracena, Cazalla de la Sierra, Villanueva de Córdoba, Benamahoma, Grazalema and Ubrique) during three years (data supplied by State Meteorological Agency). 
Table 2

Fatty acid and triacylglycerol profiles of Iberian pig subcutaneous fat from rump of three different years

\begin{tabular}{|c|c|c|c|c|c|c|}
\hline & \multicolumn{2}{|c|}{$\begin{array}{c}\text { HRC } \\
(n=104)\end{array}$} & \multicolumn{2}{|c|}{$\begin{array}{c}\text { MRC } \\
(n=68)\end{array}$} & \multicolumn{2}{|c|}{$\begin{array}{c}\text { LRC } \\
(n=28)\end{array}$} \\
\hline & Means & S.D. & Means & S.D. & Means & S.D. \\
\hline C14:0 & $1.15^{\mathrm{a}}$ & 0.12 & $1.25^{\mathrm{b}}$ & 0.12 & $1.16^{\mathrm{a}}$ & 0.08 \\
\hline C16:0 & 20.12 & 0.98 & 20.05 & 0.89 & 19.66 & 0.83 \\
\hline C16:1 & 1.98 & 0.31 & 2.11 & 0.33 & 2.06 & 0.25 \\
\hline C17:0 & 0.30 & 0.05 & 0.31 & 0.05 & 0.30 & 0.04 \\
\hline C17:1 & 0.28 & 0.07 & 0.28 & 0.06 & 0.28 & 0.05 \\
\hline C18:0 & $9.90^{\mathrm{a}}$ & 0.97 & $9.21^{\mathrm{b}}$ & 1.02 & $8.46^{\mathrm{b}}$ & 0.59 \\
\hline C18:1 & $55.58^{a}$ & 1.50 & $55.60^{\mathrm{a}}$ & 1.30 & $56.76^{\mathrm{b}}$ & 1.21 \\
\hline C18:2 & $8.28^{a}$ & 0.67 & $8.71^{\mathrm{b}}$ & 0.66 & $8.92^{b}$ & 0.38 \\
\hline C18:3 & $0.54^{\mathrm{a}}$ & 0.12 & $0.63^{b}$ & 0.19 & $0.63^{\mathrm{ab}}$ & 0.12 \\
\hline C20:0 & $0.20^{\mathrm{a}}$ & 0.03 & $0.19^{b}$ & 0.03 & $0.17^{\mathrm{b}}$ & 0.01 \\
\hline C20:1 & 1.66 & 0.25 & 1.67 & 0.22 & 1.62 & 0.13 \\
\hline SFA & $31.68^{\mathrm{a}}$ & 1.69 & $31.00^{\mathrm{ab}}$ & 1.60 & $29.74^{b}$ & 1.26 \\
\hline MUFA & $59.51^{\mathrm{a}}$ & 1.52 & $59.66^{\mathrm{ab}}$ & 1.37 & $60.71^{\mathrm{b}}$ & 1.15 \\
\hline PUFA & $8.82^{\mathrm{a}}$ & 0.74 & $9.33^{\mathrm{bc}}$ & 0.78 & $9.54^{c}$ & 0.44 \\
\hline PPP & $0.24^{a}$ & 0.07 & $0.17^{\mathrm{b}}$ & 0.05 & $0.10^{c}$ & 0.05 \\
\hline MOP & $0.82^{a}$ & 0.14 & $0.70^{\mathrm{b}}$ & 0.12 & $0.46^{c}$ & 0.13 \\
\hline PPS & $0.73^{a}$ & 0.18 & $0.57^{b}$ & 0.14 & $0.35^{c}$ & 0.14 \\
\hline POP & $5.38^{a}$ & 0.73 & $4.77^{\mathrm{b}}$ & 0.58 & $3.97^{c}$ & 0.58 \\
\hline POPo + PLP & $4.62^{a}$ & 0.50 & $4.56^{\mathrm{ab}}$ & 0.44 & $1.95^{b}$ & 0.35 \\
\hline PLPO + MLO & $0.83^{a}$ & 0.10 & $0.74^{\mathrm{bc}}$ & 0.12 & $0.69^{c}$ & 0.16 \\
\hline PSS & $0.97^{\mathrm{a}}$ & 0.25 & $0.88^{\mathrm{a}}$ & 0.20 & $0.58^{\mathrm{b}}$ & 0.16 \\
\hline PSO & $13.91^{\mathrm{a}}$ & 1.51 & $13.25^{\mathrm{a}}$ & 1.56 & $10.39^{b}$ & 1.22 \\
\hline POO & $31.55^{\mathrm{a}}$ & 0.95 & $31.64^{a}$ & 1.11 & $36.95^{\mathrm{b}}$ & 1.29 \\
\hline PLO & $9.78^{\mathrm{a}}$ & 0.67 & $10.88^{b c}$ & 0.95 & $10.77^{\mathrm{c}}$ & 0.49 \\
\hline PLL + PoLO & $1.45^{\mathrm{a}}$ & 0.19 & $1.36^{\mathrm{ab}}$ & 0.20 & $1.23^{\mathrm{b}}$ & 0.13 \\
\hline sos & $1.37^{\mathrm{a}}$ & 0.19 & $1.21^{\mathrm{b}}$ & 0.20 & $1.03^{c}$ & 0.08 \\
\hline SOO & 6.99 & 0.63 & 6.81 & 0.69 & 6.57 & 0.46 \\
\hline 000 & $11.08^{\mathrm{a}}$ & 1.36 & $11.52^{\mathrm{ab}}$ & 1.28 & $12.36^{\mathrm{b}}$ & 1.34 \\
\hline SOL & $3.78^{\mathrm{a}}$ & 0.22 & $3.78^{\mathrm{a}}$ & 0.40 & $4.12^{\mathrm{b}}$ & 0.68 \\
\hline OOL & $5.50^{\mathrm{a}}$ & 0.73 & $6.10^{b}$ & 0.74 & $6.99^{c}$ & 0.59 \\
\hline OLL & $1.00^{a}$ & 0.18 & $1.07^{\mathrm{a}}$ & 0.19 & $1.52^{b}$ & 0.30 \\
\hline DBN 0 & $1.94^{\mathrm{a}}$ & 0.47 & $1.62^{\mathrm{b}}$ & 0.37 & $1.02^{\mathrm{c}}$ & 0.34 \\
\hline DBN 1 & $21.48^{a}$ & 2.18 & $19.94^{\mathrm{b}}$ & 2.14 & $15.84^{c}$ & 1.83 \\
\hline DBM 2 & $43.17^{a}$ & 1.10 & $43.00^{\mathrm{a}}$ & 1.09 & $45.46^{\mathrm{b}}$ & 1.22 \\
\hline DBN 3 & $25.47^{a}$ & 1.57 & $26.92^{\mathrm{bc}}$ & 1.73 & $27.94^{c}$ & 1.10 \\
\hline DBN 4 & $6.95^{\mathrm{a}}$ & 0.83 & $7.46^{\mathrm{b}}$ & 0.86 & $8.22^{\mathrm{c}}$ & 0.61 \\
\hline R1 & 0.10 & 0.01 & 0.11 & 0.02 & 0.10 & 0.01 \\
\hline $\mathrm{R} 2$ & $5.68^{a}$ & 0.67 & $6.12^{b}$ & 0.75 & $6.75^{c}$ & 0.57 \\
\hline
\end{tabular}

Data are means and standard deviation. Means with different letters in the same raw are significantly different $(p<0.001)$

resources the \% of stearic acid in both anatomical locations decreased significantly $(p<0.001)$, $14.55 \%$ in $\mathrm{R}$ and $9.02 \%$ in $\mathrm{H}$, when compared to HRC. In accordance, the PUFA was increased by $7.54 \%$ in the $\mathrm{R}$ and by $6.48 \%$ in the $\mathrm{H}$ whereas saturated fatty acids (SFA) was decreased $6.12 \%$ and $3.89 \%$ respectively in both tissues, when comparing the LRC and HRC. On the contrary the level of MUFA was significantly $(P<0.001)$ increased by $1.98 \%$, only in the R location. Similar results were obtained by Bee et al. (2002) for animals fed experimental diets with low energy (8.8 MJ disgestive energy/kg) compared to animals fed on the same diet with high energy (14.4 MJ disgestive energy/kg). SFA decreased $12-14 \%$ while PUFA increased $39-62 \%$, and MUFA remained unchanged. The increase in
PUFA in the campaign with lower pasture and acorn availability compared to HRC could be attributed to a lower deposition of subcutaneous fat. Lipogenesis is tightly regulated by alterations in energy intake (Vernon, 1999). Bee et al. (2002) reported a decreased in the activity of the lipogenic enzyme and a lower fat deposition rate in pigs fed low energy diets. In accordance the desaturation index $\left(R_{2}\right)$ was increased in the LRC $(15.85 \%$ in $R$ and $9.97 \%$ in $H)$, suggesting an increase in SCD activity.

For the triacylglycerols, the same trends were observed in both tissue samples. The most saturated triacylglycerols were significantly decreased $(p<0.001)$ while the most unsaturated (DBN 3 to DBN 4 were significantly increased $(p<$ 0.001 ) in the LRC compared to the HRC. 
Table 3

Fatty acid and triacylglycerol profiles of Iberian pig subcutaneous fat from adipose tissue covering the Biceps femoris muscle of three different years

\begin{tabular}{|c|c|c|c|c|c|c|}
\hline & \multicolumn{2}{|c|}{$\begin{array}{c}\text { HRC } \\
(n=104)\end{array}$} & \multicolumn{2}{|c|}{$\begin{array}{c}\text { MRC } \\
(n=68)\end{array}$} & \multicolumn{2}{|c|}{$\begin{array}{c}\text { LRC } \\
(n=28)\end{array}$} \\
\hline & Means & S.D. & Means & S.D. & Means & S.D. \\
\hline C14:0 & $1.18^{\mathrm{ab}}$ & 0.14 & $1.23^{\mathrm{a}}$ & 0.10 & $1.13^{b}$ & 0.09 \\
\hline C16:0 & 20.68 & 1.19 & 20.40 & 1.02 & 20.45 & 1.06 \\
\hline C16:1 & $2.03^{\mathrm{a}}$ & 0.33 & $2.09^{\mathrm{a}}$ & 0.33 & $1.75^{\mathrm{b}}$ & 0.21 \\
\hline C17:0 & 0.28 & 0.06 & 0.30 & 0.05 & 0.26 & 0.04 \\
\hline C17:1 & 0.26 & 0.07 & 0.26 & 0.06 & 0.24 & 0.04 \\
\hline C18:0 & $10.31^{\mathrm{a}}$ & 1.20 & $9.64^{b c}$ & 1.10 & $9.38^{\mathrm{c}}$ & 0.74 \\
\hline C18:1 & 55.00 & 1.70 & 55.36 & 1.58 & 56.09 & 1.38 \\
\hline C18:2 & $7.99^{a}$ & 0.76 & $8.38^{b c}$ & 0.64 & $8.51^{\mathrm{c}}$ & 0.48 \\
\hline C18:3 & 0.53 & 0.14 & 0.58 & 0.15 & 0.58 & 0.11 \\
\hline C20:0 & $0.20^{a}$ & 0.03 & $0.19^{a b}$ & 0.03 & $0.17^{b}$ & 0.02 \\
\hline C20:1 & 1.54 & 0.23 & 1.59 & 0.19 & 1.43 & 0.18 \\
\hline SFA & 32.66 & 2.08 & 31.75 & 1.92 & 31.39 & 1.71 \\
\hline MUFA & 58.30 & 5.64 & 59.29 & 1.69 & 59.51 & 1.43 \\
\hline PUFA & $8.51^{\mathrm{a}}$ & 0.85 & $8.95^{\mathrm{b}}$ & 0.72 & $9.10^{\mathrm{ab}}$ & 0.55 \\
\hline PPP & $0.24^{\mathrm{a}}$ & 0.09 & $0.16^{b}$ & 0.05 & $0.10^{c}$ & 0.04 \\
\hline MOP & $0.80^{\mathrm{a}}$ & 0.19 & $0.70^{b}$ & 0.13 & $0.45^{c}$ & 0.08 \\
\hline PPS & $0.76^{a}$ & 0.23 & $0.61^{b}$ & 0.17 & $0.45^{c}$ & 0.13 \\
\hline POP & $5.41^{\mathrm{a}}$ & 0.97 & $4.86^{\mathrm{bc}}$ & 0.69 & $4.34^{c}$ & 0.66 \\
\hline POPO + PLP & $4.48^{\mathrm{a}}$ & 0.57 & $4.45^{\mathrm{a}}$ & 0.50 & $1.74^{b}$ & 0.31 \\
\hline PLPO + MLO & $0.77^{\mathrm{a}}$ & 0.11 & $0.68^{\mathrm{bc}}$ & 0.11 & $0.61^{c}$ & 0.07 \\
\hline PSS & $1.03^{\mathrm{a}}$ & 0.33 & $0.93^{\mathrm{a}}$ & 0.27 & $0.66^{\mathrm{b}}$ & 0.18 \\
\hline PSO & $14.82^{\mathrm{a}}$ & 1.94 & $13.81^{\mathrm{a}}$ & 1.84 & $12.28^{b}$ & 1.40 \\
\hline $\mathrm{POO}$ & $31.74^{\mathrm{a}}$ & 0.99 & $31.44^{\mathrm{a}}$ & 1.55 & $36.50^{b}$ & 1.11 \\
\hline PLO & $9.56^{a}$ & 0.75 & $10.35^{\mathrm{b}}$ & 0.99 & $10.04^{\mathrm{ab}}$ & 0.62 \\
\hline PLL + PoLO & 1.29 & 0.18 & 1.24 & 0.21 & 1.24 & 0.18 \\
\hline SOS & 1.40 & 0.22 & 1.40 & 0.64 & 1.29 & 0.16 \\
\hline SOO & 6.93 & 0.69 & 7.01 & 0.87 & 6.87 & 0.59 \\
\hline 000 & 10.89 & 1.62 & 11.43 & 1.46 & 11.99 & 1.19 \\
\hline SOL & $3.58^{a}$ & 0.30 & $3.77^{\mathrm{b}}$ & 0.34 & $3.53^{\mathrm{ab}}$ & 0.30 \\
\hline OOL & $5.30^{\mathrm{a}}$ & 0.88 & $6.15^{b c}$ & 0.84 & $6.50^{\mathrm{c}}$ & 0.60 \\
\hline OLL & $0.98^{\mathrm{a}}$ & 0.25 & $1.00^{\mathrm{a}}$ & 0.18 & $1.41^{b}$ & 0.28 \\
\hline DBN 0 & $2.03^{\mathrm{a}}$ & 0.60 & $1.71^{\mathrm{b}}$ & 0.46 & $1.21^{\mathrm{c}}$ & 0.32 \\
\hline DBN 1 & $22.44^{\mathrm{a}}$ & 2.83 & $20.77^{\mathrm{b}}$ & 2.81 & $18.36^{c}$ & 1.94 \\
\hline DBM 2 & $43.16^{a}$ & 1.13 & $42.90^{\mathrm{a}}$ & 1.14 & $45.12^{b}$ & 0.94 \\
\hline DBN 3 & $24.80^{a}$ & 2.04 & $26.24^{b}$ & 1.99 & $26.17^{\mathrm{ab}}$ & 1.41 \\
\hline DBN 4 & $6.59^{\mathrm{a}}$ & 0.99 & $7.39^{\mathrm{bc}}$ & 0.92 & $7.74^{c}$ & 0.68 \\
\hline $\mathrm{R} 1$ & $0.10^{\mathrm{a}}$ & 0.01 & $0.10^{\mathrm{a}}$ & 0.02 & $0.09^{b}$ & 0.01 \\
\hline $\mathrm{R} 2$ & $5.42^{\mathrm{a}}$ & 0.74 & $5.83^{b c}$ & 0.76 & $6.02^{c}$ & 0.58 \\
\hline
\end{tabular}

Data are means and standard deviation. Means with different letters in the same raw are significantly different $(p<0.001)$

\section{3. "Montanera" feeding length}

Table 4 shows the mean content in percentage of triacylglycerols and fatty acids of Iberian pig subcutaneous fat form $\mathrm{H}$ and $\mathrm{R}$ according to the two types of "Montanera" (M1 and M2). The statistic analysis of the results showed significant differences for some fatty acids and triacylglycerols for M1 and $\mathrm{M} 2$, although the fatty acids and triacylglycerols affected were different depending on the anatomical location $(H$ or $R)$. Therefore, in the case of $R$ location, margaric acid was significantly $(p<0.05)$ lower for M1 than for M2 while myristic was higher. On the contrary, for $\mathrm{H}$ location margaroleic acid, linoleic acid and PUFA showed significant $(p<$ 0.001 ) lower values for short "Montanera", while arachidic acid was significantly higher $(p<0.05)$.
In the case of triacylglycerols from $\mathrm{R}$ location, there were significant differences for POPo + PLP, PLPo + MLO, OLL $(p<0.05)$, PLL + PoLO $(p<$ $0.01)$ and SOL $(p<0.001)$. The first of them (the most saturated) showed higher values for M1, while the others (with more unsaturation) showed higher values for M2. In the same way, and for $\mathrm{H}$ location, there were significant differences for POPo + PLP, PLPo + MLO, PSO, PLO, SOS, OOL $(p<0.05)$, PLL + PoLO and OLL $(p<0.0001)$, showing the most saturated (POPo + PLP, PSO, and SOS) a higher value for $\mathrm{M} 1$ and the triacylglycerols with higher unsaturation, a higher value for $\mathrm{M} 2$.

These results are in agreement with the previous studies made by others authors (Cava López and Andrés Nieto, 2001), whom confirm that the length of fattening period has a great 
Tabla 4

Fatty acid and triacylglycerol profiles of Iberian pig subcutaneous fat from two anatomical locations for two different periods of "Montanera"

\begin{tabular}{|c|c|c|c|c|c|c|c|c|c|}
\hline \multicolumn{6}{|c|}{$\mathbf{R}$} & \multicolumn{4}{|c|}{$\mathbf{H}$} \\
\hline & \multicolumn{2}{|c|}{$\begin{array}{c}M 1 \\
(n=46)\end{array}$} & \multicolumn{2}{|c|}{$\begin{array}{c}\text { M2 } \\
(n=154)\end{array}$} & & \multicolumn{2}{|c|}{$\begin{array}{c}M 1 \\
(n=46)\end{array}$} & \multicolumn{2}{|c|}{$\begin{array}{c}\text { M2 } \\
(n=154)\end{array}$} \\
\hline & Means & S.D. & Means & S.D. & & Means & S.D. & Means & S.D. \\
\hline $\mathrm{C} 14: 0^{\mathrm{a}}$ & 1,22 & 0,11 & 1,17 & 0,13 & C14:0 & 1.19 & 0.10 & 1.19 & 0.13 \\
\hline C16:0 & 19,96 & 0,92 & 20,05 & 0,95 & C16:0 & 20.68 & 1.11 & 20.52 & 1.12 \\
\hline C16:1 & 2,05 & 0,27 & 2,03 & 0,33 & C16:1 & 2.02 & 0.32 & 2.01 & 0.34 \\
\hline $\mathrm{C} 17: 0^{\mathrm{a}}$ & 0,29 & 0,05 & 0,31 & 0,05 & $\mathrm{C} 17: 0$ & 0.27 & 0.06 & 0.29 & 0.05 \\
\hline C17:1 & 0,26 & 0,06 & 0,28 & 0,06 & $\mathrm{C} 17: 1^{\mathrm{c}}$ & 0.23 & 0.06 & 0.27 & 0.06 \\
\hline C18:0 & 9,46 & 1,04 & 9,46 & 1,09 & C18:0 & 10.25 & 1.30 & 9.86 & 1.12 \\
\hline C18:1 & 55,91 & 1,17 & 55,71 & 1,52 & C18:1 & 55.25 & 1.46 & 55.28 & 1.71 \\
\hline C18:2 & 8,39 & 0,70 & 8,55 & 0,67 & C18: $2^{C}$ & 7.85 & 0.76 & 8.30 & 0.67 \\
\hline C18:3 & 0,55 & 0,16 & 0,59 & 0,15 & C18:3를 & 0.51 & 0.14 & 0.56 & 0.14 \\
\hline C20:0 & 0,20 & 0,03 & 0,19 & 0,03 & $\mathrm{C} 20: 0^{\mathrm{a}}$ & 0.20 & 0.03 & 0.19 & 0.03 \\
\hline C20:1 & 1,70 & 0,26 & 1.65 & 0.22 & C20:1 & 1.56 & 0.21 & 1.53 & 0.22 \\
\hline SFA & 31,13 & 1,69 & 31,19 & 1,74 & SFA & 32.59 & 2.14 & 32.05 & 2.00 \\
\hline MUFA & 59,92 & 1,27 & 59,67 & 1,53 & MUFA & 59.05 & 1.61 & 58.73 & 4.76 \\
\hline PUFA & 8,94 & 0,79 & 9,14 & 0,77 & PUFA $^{\mathrm{C}}$ & 8.36 & 0.84 & 8.86 & 0.77 \\
\hline PPP & 0,20 & 0,07 & 0,19 & 0,08 & PPP & 0.21 & 0.09 & 0.19 & 0.09 \\
\hline MOP & 0,75 & 0,14 & 0,72 & 0,19 & MOP & 0.77 & 0.17 & 0.70 & 0.20 \\
\hline PPS & 0,63 & 0,19 & 0,62 & 0,22 & PPS & 0.72 & 0.24 & 0.65 & 0.22 \\
\hline POP & 5,00 & 0,69 & 4,97 & 0,86 & POP & 5.30 & 0.90 & 5.01 & 0.93 \\
\hline $\mathrm{POPO}+\mathrm{PLP}^{\mathrm{a}}$ & 4,49 & 0,63 & 4,15 & 1,11 & $\mathrm{POPo}+\mathrm{PLP}^{\mathrm{a}}$ & 4.42 & 0.65 & 3.99 & 1.16 \\
\hline$P L P O+M L O^{a}$ & 0,74 & 0,13 & 0,79 & 0,13 & PLPO $+M L O^{a}$ & 0.68 & 0.13 & 0.73 & 0.11 \\
\hline PSS & 0,91 & 0,22 & 0,88 & 0,27 & PSS & 1.01 & 0.39 & 0.92 & 0.30 \\
\hline PSO & 13,48 & 1,66 & 13,11 & 1,96 & $\mathrm{PSO}^{\mathrm{a}}$ & 14.69 & 2.26 & 13.96 & 1.93 \\
\hline $\mathrm{POO}$ & 31,94 & 1,26 & 32,46 & 2,33 & $\mathrm{POO}$ & 31.82 & 2.01 & 32.45 & 2.10 \\
\hline PLO & 10,23 & 0,99 & 10,31 & 0,90 & $\mathrm{PLO}^{\mathrm{a}}$ & 9.67 & 1.20 & 9.96 & 0.78 \\
\hline PLL + PoLO & 1,31 & 0,22 & 1,41 & 0,19 & PLL + PoLO & 1.15 & 0.22 & 1.30 & 0.17 \\
\hline SOS & 1,29 & 0,21 & 1,26 & 0,22 & $\operatorname{sOS}^{a}$ & 1.49 & 0.76 & 1.35 & 0.22 \\
\hline SOO & 6,98 & 0,72 & 6,83 & 0,62 & SOO & 7.12 & 0.96 & 6.90 & 0.66 \\
\hline 000 & 11,61 & 1,25 & 11,35 & 1,43 & 000 & 11.04 & 1.47 & 11.29 & 1.58 \\
\hline $\mathrm{SOL}^{\mathrm{c}}$ & 3,65 & 0,33 & 3,88 & 0,40 & SOL & 3.57 & 0.46 & 3.66 & 0.27 \\
\hline OOL & 5,77 & 0,76 & 5,95 & 0,91 & $\mathrm{OOL}^{\mathrm{a}}$ & 5.47 & 1.08 & 5.84 & 0.91 \\
\hline $\mathrm{OLL}^{\mathrm{a}}$ & 1,01 & 0,20 & 1,13 & 0,28 & OLL $^{d}$ & 0.88 & 0.20 & 1.09 & 0.28 \\
\hline DBN 0 & 1,73 & 0,45 & 1,69 & 0,54 & DBN 0 & 1.94 & 0.67 & 1.76 & 0.57 \\
\hline DBN1 & 20,53 & 2,38 & 20,06 & 2,95 & $\mathrm{DBN} 1^{\mathrm{a}}$ & 22.24 & 3.48 & 21.02 & 2.87 \\
\hline DBM 2 & 43,41 & 0,95 & 43,44 & 1,49 & DBM 2 & 43.36 & 1.21 & 43.34 & 1.35 \\
\hline DBN 3 & 26,24 & 1,84 & 26,33 & 1,82 & DBN 3 & 24.96 & 2.49 & 25.64 & 1.91 \\
\hline DBN 4 & 7,08 & 0,90 & 7,36 & 0,92 & $\mathrm{DBN} 4^{\mathrm{b}}$ & 6.62 & 1.17 & 7.14 & 0.96 \\
\hline $\mathrm{R} 1$ & 0,10 & 0,01 & 0,10 & 0.01 & $\mathrm{R} 1$ & 0.10 & 0.02 & 0.10 & 0.02 \\
\hline $\mathrm{R} 2$ & 5,98 & 0,74 & 5,97 & 0,79 & $\mathrm{R} 2$ & 5.49 & 0.83 & 5.69 & 0.74 \\
\hline
\end{tabular}

Data are means and standard deviation. Superscripts indicate significant differences between $\mathrm{M} 1$ and $\mathrm{M} 2 \mathrm{for}$ each location ( $\mathrm{H}$ and $\mathrm{R}$ ): a for $p<0.05$, b for $p<0.01$, c for $p<0.001$ and $d$ for $p<0.0001$.

importance in the characteristics of composition in fatty acids of fat. In general, when the length of fattening period is increased, the profile of the fat is similar to the profile of food, in this case acorn and pasture. The saturated fatty acids, palmitic and stearic, and therefore the triacylglycerols that contain them, decrease, while the unsaturated fatty acids and the triacylglycerols that contain them increase (Daza et al., 2007; Díaz et al., 1996). In accordance with bibliography (Viera-Alcaide et al., 2008), an increase in the content of OOL was observed for both location when increasing the feeding length.

To confirm this fact, the mean differences between subcutaneous fat from $R$ and $H$ were calculated. Figures 2 and 3 show the evolutions of these differences throughout the time of "Montanera" for fatty acids and triacylglycerols respectively with significant differences. In these figures, it can be observed that the saturated fatty acids and triacylglicerols that contain them in a great proportion (DBN 1) show an increase of these differences throughout the fattening period. This fact shows that the decrease in the levels of these compounds takes place at a faster rate in the anatomical location $\mathrm{H}$. However, the higherunsaturated fatty acids and triacylglycerols show a decrease of those significant differences throughout the fattening period, it also indicates that there is a faster rate in the anatomical location $\mathrm{H}$. These facts 

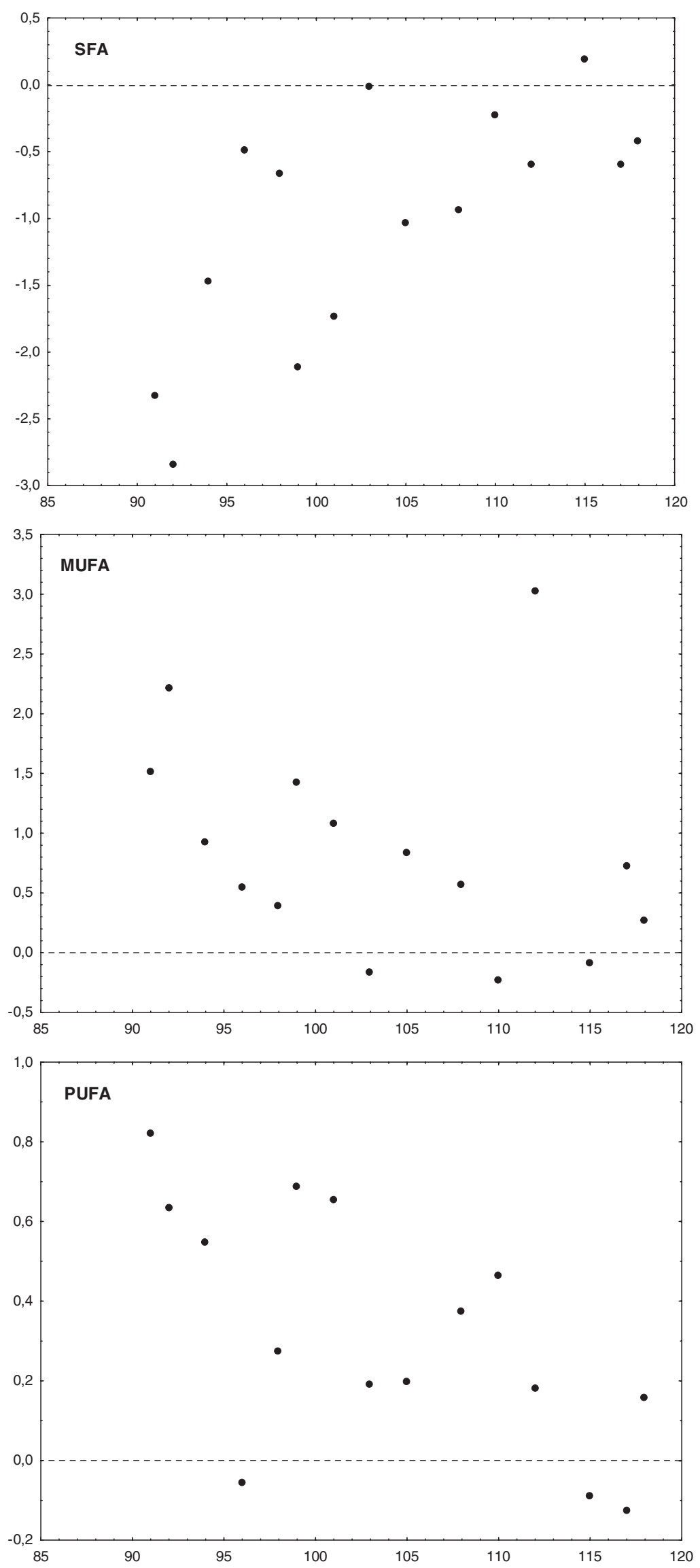

Figure 2.

Evolution of the differences between subcutaneous fat from rump $(\mathrm{R})$ and adipose tissue covering the Biceps femoris muscle $(\mathrm{H})$ of different fatty acids gruping as SFA, MUFA and PUFA vs time for long "Montanera" (in days). 

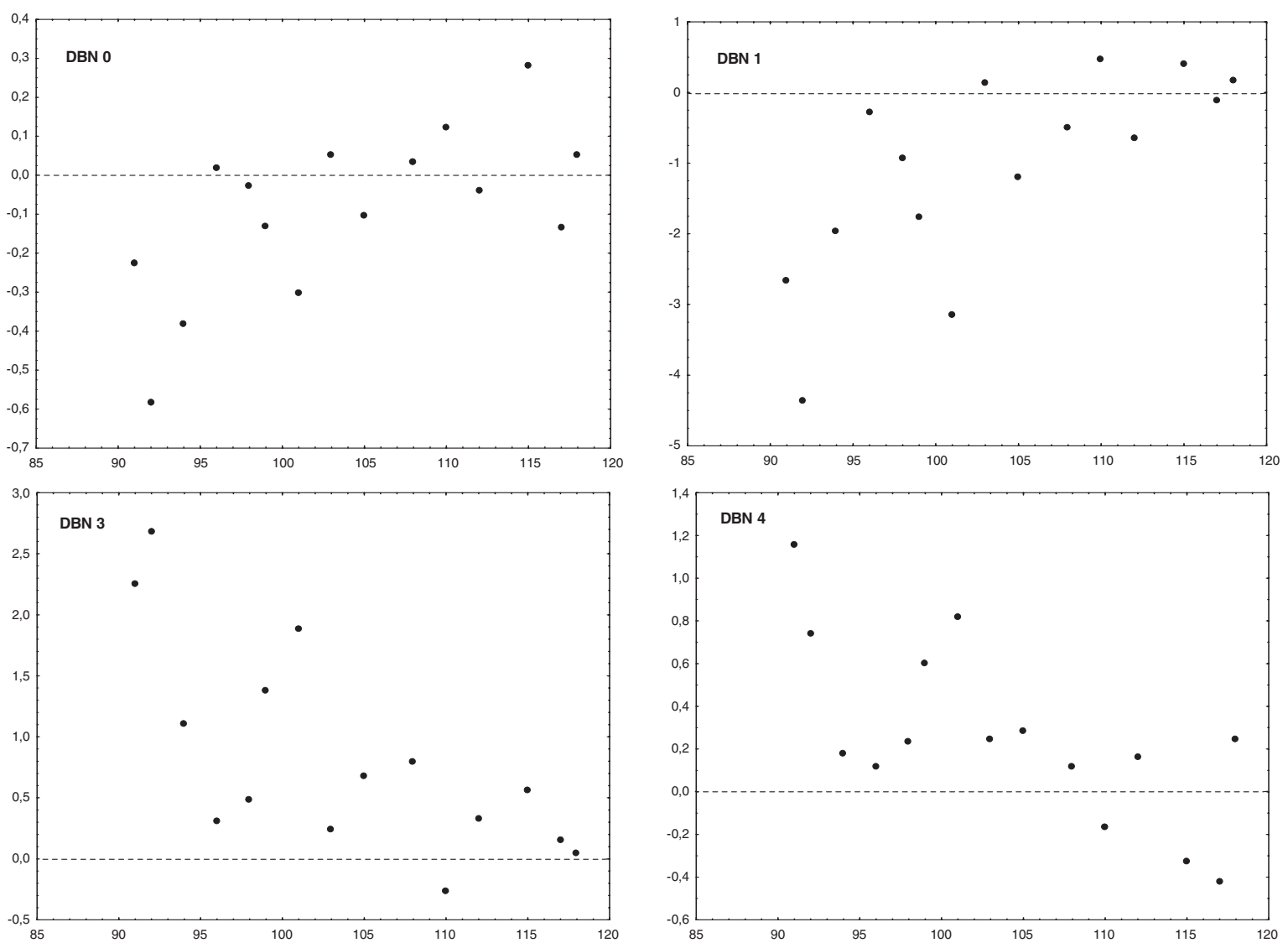

Figure 3.

Evolution of the differences between subcutaneous fat from rump $(\mathrm{R})$ and adipose tissue covering the Biceps femoris muscle $(\mathrm{H})$ of different triacylglycerols gruping as DBN vs time for long "Montanera" (in days).

agree with the values of enzymatic activity calculated as $R_{2}$, which presents a higher value in $\mathrm{H}$ for long "Montanera" period. According to previous studies (Muriel et al., 2002), the unsaturation of the subcutaneous fat covering a muscle with high oxidative metabolism, as $B$. femoris, increase faster than the subcutaneous fat covering a muscle with low oxidative metabolism, as L. dorsi.

\section{ACKNOWLEDGEMENTS}

The authors are grateful to the Designation of Origin "Jamón de Huelva" especially to Mr. J. de Mier for the collaboration and given help and Dr. A. Garrido for the scientific assistance.

\section{REFERENCES}

Bee G, Gebert S, Messikommer R. 2002. Effect of dietary energy supply and fat source on the fatty acid pattern of adipose and lean tissues and lipogenesis in the pig. J. Anim. Sci. 80, 1564-1574.

Bee G, Jacot S, Guex G, Biolley C. 2008. Effects of two supplementation levels of linseed combined with CLA or tallow on meat quality traits and fatty acid profile of adipose and different muscle tissues in slaughter pigs. Animal. 2, 800-811.
Boletín Oficial del Estado (BOE) (2004). Orden PRE/3844/2004 por la que se establecen los métodos oficiales de toma de muestras en canales de cerdos ibéricos y el método de análisis para la determinación de la composición de ácidos grasos de los lípidos totales del tejido adiposo subcutáneo de cerdos ibéricos. (pp. 38770-38775). Madrid, Spain.

Boletín Oficial del Estado (BOE) (2007). REAL DECRETO 1469/2007, de 2 de noviembre, por el que se aprueba la norma de calidad para la carne, el jamón, la paleta y la caña de lomo ibéricos. (pp. 45087-45104). Madrid, Spain.

Buller KJ, Enser M. 1986. The effect of food-intake and dietary fatty-acids on the activity of stearoyl-CoA $\Delta^{9}$ desaturase in pig adipose-tissue. J. Agric. Sci. 106, 601-609.

Cava R, Ruíz J, López Bote C, Marín L, García C, Ventanas J. 1997. Influence of finishing diets on fatty acid profiles of intramuscular lipids, triglycerides and phospolipids in muscles of the Iberian pig. Meat Sci. 45, 263-270.

Cava López R, Andrés Nieto Al. 2001. La obtención de materia prima de una adecuada aptitud tecnológica. Características de la grasa determinantes de la calidad del jamón: Influencia de los factores genéticos y ambientales, en Mundi-Prensa (Ed.) Tecnología del jamón Ibérico: De los sistemas tradicionales a la explotación racional del sabor y el aroma, 1st ed. J. Ventanas, Madrid, págs. 99-130.

Daza A, Mateos A, Rey Al, Ovejero I, López-Bote CJ. 2007. Effect of duration of feeding under free-range 
conditions on production results and carcass and fat quality in Iberian pigs. Meat Sci. 76, 411-416.

De Pedro E, Casillas M, Miranda CM. 1997. Microwave Oven Application in the Extraction of Fat from the Subcutaneous Tissue of Iberian Pig Ham. Meat Sci. 45, 45-51.

Díaz I, García Regueiro JA, Casillas M, De Pedro E. 1996. Triglyceride composition of fresh ham fat from Iberian pigs produced with different systems of animal nutrition. Food Chem. 55, 383-387.

Franco I, Escamilla MC, García J, García Fontán MC, Carballo J. 2006. Fatty acid profile of the fat from Celta pig breed fattened using a traditional feed: Effect of the location in the carcass. J. Food Comp. Anal. 19, 792-799.

García C, Ventanas J, Antequera T, Ruíz J, Cava R, Alvarez P. 1996. Measuring sensorial quality of Iberian Ham by Rash model. J. Food Qual. 19, 397-412.

García-Mozo H, Gómez-Casero MT, Domínguez E, Galán C. 2007. Influence of pollen emission and weather-related factors on variations in holm-oak (Quercus ilex subsp. ballota) acorn production. Environ. Exp. Bot.. 61, 35-40.

García-Rey RM, Quiles-Zafra R, Luque de Castro MD. 2005. Effect of genotype and seasonality on pig carcass and meat characteristics. Livest Prod. Sci. 96, 175-183.

Klingenberg IL, Knabe DA, Smith SB. 1995. Lipid metabolism in pigs fed beef tallow or high-oleic acid sunflower oil. Comp. Biochem Physiol. 110, 183-192.

Kouba M, Mourot J. 1998. Effect of a high linoleic acid diet on $\Delta 9$-desaturase activity, lipogenesis and lipid composition of pig subcutaneous adipose tissue. Reprod Nutr. Dev. 38, 31-37.

Kouba M, Mourot J, Peiniau P. 1997. Stearoyl-CoA desaturase activity in adipose tissues and liver of growing Large White and Meishan pigs. Comp. Biochem Physiol. 118B, 509-514.

León-Camacho M, Viera-Alcaide I, Vicario IM. 2004. Acorn (Quercus spp.) Fruit lipids: Saponifiable and Unsaponifiable fractions: a detail study. JAOCS. 81, 447-453.

López Bote CJ. 1998. Sustained utilization of the iberian pig breed. Meat Sci. 49 (suppl), S17-S27.

Monziols M, Bonneau M, Davenel A, Kouba M. 2007. Comparison of the lipid content and fatty acid composition of intermuscular and subcutaneous adipose tissues in pig carcasses. Meat Sci. 76, 54-60.

Muriel E, Ruiz J, Ventanas J, Antequera T. 2002. Freerange rearing increases ( $n-3)$ polyunsaturated fatty acids of neutral and polar lipids in swine muscles. Food Chem. 78, 219-225.

Narváez-Rivas M, Vicario MI, Graciani Constante E, León-Camacho M. 2008. Changes in the Fatty Acid and Triacylglycerol Profiles in the Subcutaneous fat of Iberian Ham during the Dry-Curing Process. J. Agric. Food Chem. 56, 7131-7137.

Rodríguez-Estévez V, García A, Peña F, Gómez AG. 2008. Foraging of Iberian fattening pig grazing natural pasture in the dehesa. Livestock Sci. doi:10.1016/j.livsci.2008.05.006.

Rodríguez-Estévez V, García A, Perea J, Mata C, Gómez AG. 2007. Producción de bellota en la dehesa: factores influyentes. Arch. Zootec. 56 (R), 25-43.

Sharma N, Gandemer G, Goutefongea R. 1987. Comparative Lipid Composition of porcine muscles at different anatomical locations. Meat Sci. 19, 121-128.

StatSoft Inc. (2008) Statistica 8.0 for Windows Computer Program Manual, Tulsa, OK. Statsoft, Inc., 2300 East $14^{\text {th }}$ Street, Tulsa, OK 74104.

Tejeda JF, Gandemer G, Antequera T, Viau M, García C. 2002. Lipid traits of muscles as related to genotype and fattening diet in Iberian pigs: total intramuscular lipids and triacylglycerols. Meat Sci. 60, 357-360.

Vernon RG, Barber MC, Travers MT. 1999. Present and future studies on lipogenesis in animals and human subjects. Proc. Nutr. Soc. 58, 541-549.

Viera-Alcaide I, Vicario IM, Graciani Constante E, LeónCamacho M. 2007. Authentication of fattening diet of Iberian pig according to their triacylglycerols profile from subcutaneous fat. Anal. Chim. Acta. 596, 319324.

Viera-Alcaide I, Vicario IM, Escudero-Gilete ML, Graciani Constante E, León-Camacho M. 2008. A multivariate study of the triacylglycerols composition of the subcutaneous adipose tissue of Iberian pig in relation to the fattening diet and genotype. Grasas y Aceites. 59, 327-336. 